X. CHU, L. SHEN, B, LI, P. YANG, C. DU, X, WANG, G, HE, S. MESSAOUDI*, G. CHEN* (UNIVERSITY PARIS-SACLAY, CHÂTENAY-MALABRY, FRANCE AND NANKAI UNIVERSITY, TIANJIN, P. R. OF CHINA)

Construction of Peptide Macrocycles via Palladium-Catalyzed Multiple S-Arylation: An Effective Strategy to Expand the Structural Diversity of Cross-Linkers

Org. Lett. 2021, 23, 8001-8006, DOI: 10.1021/acs.orglett.1c03003.

\section{Palladium-Catalyzed Multiple S-Arylation for the Synthesis of Macrocyclic Peptides}
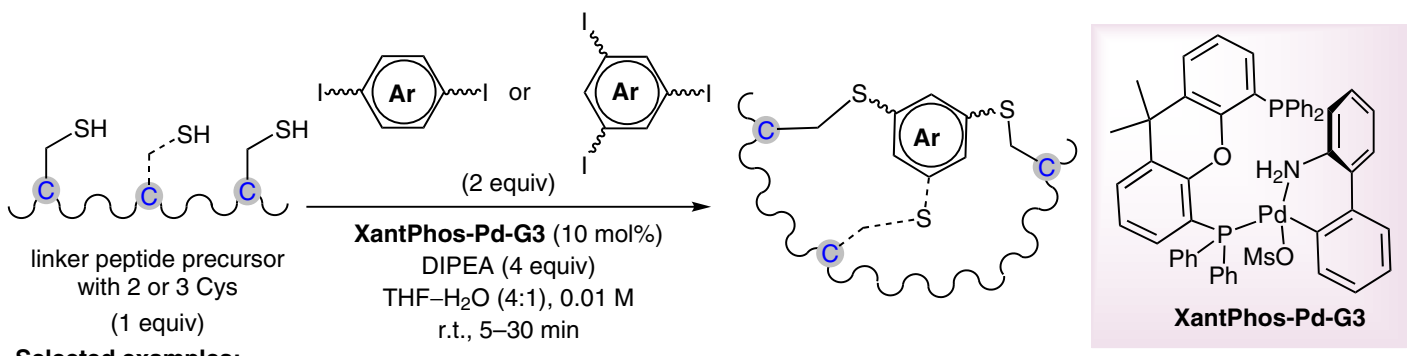

Selected examples:

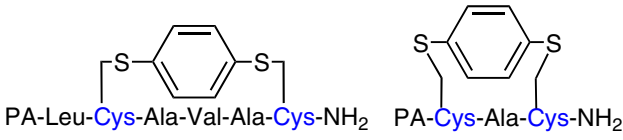

H-Ala-Gly-Cys-Lys-Asn-Phe-Phe-Trp-Lys-Thr-Phe-Thr-Ser-Cys- $\mathrm{NH}_{2}$

$84 \%(66 \%)$ yield $^{2}$

$70 \%(56 \%)$ yield $^{a}$

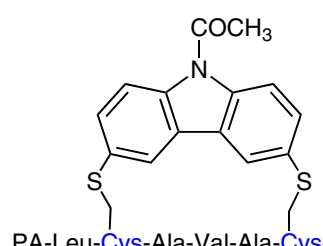

PA-Leu-Cys-Ala-Val-Ala-Cys- $\mathrm{NH}_{2}$ $79 \%(63 \%)$ yield $^{2}$

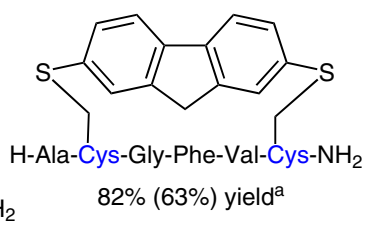

\section{PA-Leu-Cys-Ala-Val-Ala-Cys- $\mathrm{NH}_{2}$} $75 \%(63 \%)$ yield $^{\mathrm{a}}$
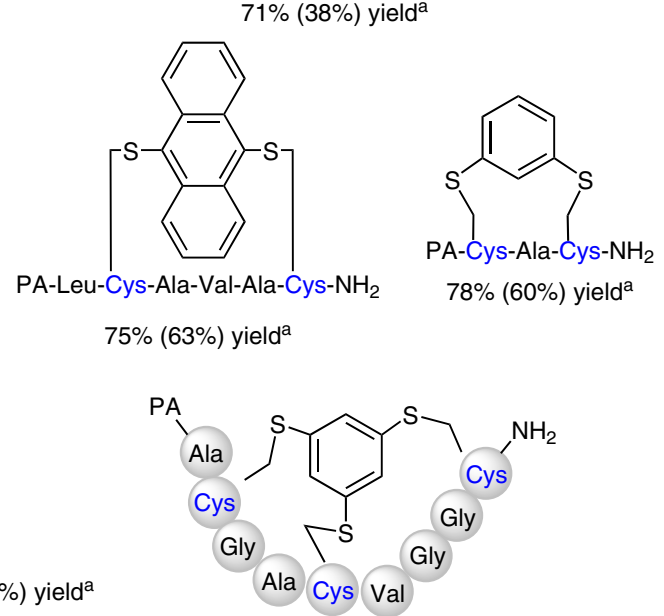

$52 \%(37 \%)$ yield $^{a}$

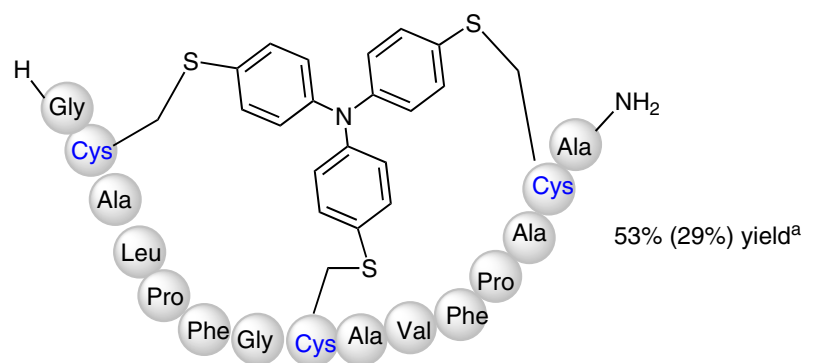

a LC yields were based on the UV absorption of peptides, HPLC isolated yields are shown in parentheses.

Significance: Macrocyclic peptides are highly demanding targets in the field of peptide-drug discovery. The authors have developed an unprecedented macrocyclization of native peptides containing cysteine residues by reaction with di- or triiodo(het) arenes with the help of a palladium catalyst.
Comment: The palladium-catalyzed multiple Sarylation of cysteine residues of unprotected native peptides with di- or triiodo(het)arenes proceeded smoothly to afford the desired macrocyclic peptides in good yields. This method is practically simple and is one of the most powerful methods for the production of cross-linked peptide macrocycles. 